\title{
TINDAK TUTUR ILOKUSI GURU BAHASA INDONESIA PADA PROSES PEMBELAJARAN DI KELAS XI IPA 1 SMAN 9 KOTA BENGKULU
}

\author{
Sitti Hajija ${ }^{1}$, Suryadi ${ }^{2}$, dan ${ }^{3}$ Bambang Djunaidi \\ ${ }^{1,2,3}$ Program Studi Pendidikan Bahasa dan Sastra Indonesia, \\ Jurusan Pendidikan Bahasa dan Seni \\ FKIP Universitas Bengkulu \\ Sittihajiia683@yahoo.com
}

\begin{abstract}
Abstrak
Tujuan penelitian ini adalah untuk mendeskripsikan tindak tutur ilokusi guru bahasa Indonesia pada proses pembelajaran di kelas XI IPA 1 SMA Negeri 9 Kota Bengkulu. Metode yang digunakan dalam penelitian ini adalah metode deskriptif kualitatif. Data dalam penelitian ini berupa tindak tutur ilokusi guru bahasa Indonesia dalam proses pembelajaran kelas XI IPA 1 SMA N 9 Kota Bengkulu. Sumber data penelitian ini adalah interaksi antara gurubahasa Indonesia dan siswa dalam proses pembelajaran di kelas XI IPA 1 SMA Negeri 9 Kota Bengkulu. Teknik pengumpulan data menggunakan teknik rekaman. Teknik analisis data dalam penelitian ini dilakukan melalui langkah-langkah yaitu: (1) Pentranskripsian data ujaran atau tindak tutur guru dalam proses pembelajaran. (2) Pengkodean data. (3) Pengklasifikasian data. (4) Penginterpretasian data. (5) Penyimpulan data. Uji keabsahan data dengan tiga teknik yakni teknik observasi, wawancara, dan teknik rekam untuk sumber data yang sama secara serentak. Hasil penelitian ditemukan jenis tindak tutur ilokusi asertif, direktif, ekspresif dan komisif, dan tidak ditemukan jenis tindak tutur ilokusi deklarasi. Contoh tindak tutur ilokusi asertif meliputi tindak tutur ilokusi asertif menyatakan informasi, tindak tutur ilokusi asertif mengemukakan pendapat, tindak tutur ilokusi asertif kesimpulan, dan tindak tutur ilokusi asertif menegaskan. Contoh tindak tutur ilokusi direktif yaitu tindak tutur ilokusi direktif memerintah, dan tindak tutur ilokusi direktif meminta yang memiliki variasi di antaranya tindak tutur ilokusi direktif meminta respons, dan tindak tutur ilokusi direktif meminta menjawab. Contoh tindak tutur ilokusi komisif meliputi tindak tutur ilokusi komisif berjanji dan tindak tutur ilokusi komisif menolak.
\end{abstract}

Kata Kunci: Tindak tutur, proses pembelajaran, guru bahasa Indonesia.

\begin{abstract}
The purpose of this study is to describe the speech acts ilokusi Indonesian teachers on the learning process in class XI IPA 1 SMA Negeri 9 Kota Bengkulu academic year 2016/2017. The method used in this research is descriptive qualitative method. The data in this research is in the form of speech acts ilokusi Indonesian language teacher in the process of learning class XI IPA 1 SMA N 9 Kota Bengkulu. The source of this research data is the interaction between gurubahasa Indonesia and students in the learning process in class XI IPA 1 SMA Negeri 9 Kota Bengkulu academic year 2016/2017. Technique of collecting data using documentation method. Technique of data analysis in this research done through steps that are: (1) Pentranskripsian speech data or speech acting teacher in process of learning. (2) Data encoding. (3) Data classification. (4) Interpretation of data. (5) Data deduction. Test the validity of data with three techniques namely observation techniques, interviews, and recording techniques for the same data source simultaneously. The results of the research
\end{abstract}


were found to be assertive, directive, expressive and commissive illustrations, and no type of speech declaration action was found. Examples of acute illicit illustrative acts include acute illusionary speech acts declaring information, assertiveness acting speech acts expressing opinions, assertiveness assertion of assumptions, and assertive illiterative acknowledgment acts. Examples of illustrative actions of directive directive are directive illocution directive actions, and the act of directive speech of the directive requesting which has variations such as the act of the directive dirokusi directive requests the response, and the act of the directive dirokusi directive asks for answering. Examples of commissive illusory speech acts include commissive comic action speech acts promised and commissive illustrative actions of speech refusing.

\section{Keywords: Act, learning process, Indonesian teachers.}

\section{PENDAHULUAN}

Dalam berkomunikasi tentu tidak terlepas adanya tindak tutur. Tindak tutur itu sendiri merupakan bagian kajian ilmu pragmatik. Tindak tutur adalah suatu tindakan yang ditampilkan lewat tuturan. (Yule, 1996:82).

Peneliti memfokuskan pada tindak tutur ilokusi karena sangat berkaitan dengan proses pembelajaran yang di dalamnya terjadi interaksi antara guru dan peserta didik, yang memiliki maksud tuturan sesuai dengan konteks yang terjadi. Searle tidak berhenti pada penggolongan tindak tutur menjadi tiga, namun kemudian menggolongkan tindak ilokusi menjadi lima macam bentuk tuturan, yaitu asertif, direktif, ekspresif, komisif, dan deklarasi.

Tindak tutur tidak terlepas dari interaksi yang melibatkan dua pihak, yaitu penutur dan lawan tutur, di dalam waktu, tempat, dan situasi tertentu. Interaksi yang berlangsung di antaranya interaksi antara seorang pedagang dan pembeli di pasar, acara diskusi di ruang kuliah, rapat dinas di kantor, sidang di pengadilan, dan proses pembelajaran yang dilakukan di lembaga pendidikan formal. Proses pembelajaran adalah segala kegiatan belajar atau interaksi dalam belajar antara guru dan siswa yang berisi penyampaian materi pembelajaran.
Berdasarkan uraian di atas peneliti tertarik untuk meneliti Bagaimana tindak tutur ilokusi guru bahasa Indonesia pada proses pembelajaran di kelas XI IPA 1 SMA Negeri 9 Kota Bengkulu.

$$
\text { Wacana ialah cara ujaran-ujaran }
$$
saling berhubungan, siapa yang menguasai wacana, bagaimana melakukan tes kontrol, apakah partisipan lainnya mengambil alih, bagaimana peran penutur dan pendengar ketika terjadi peralihan dari satu peserta ke peserta lain, bagaimana topik baru diperkenalkan dan topik lama berakhir, bukti linguistik apa yang ada untuk unit wacana yang lebih besar daripada ujaran seperti giliran berbicara dalam percakapan atau teksteks tulisan, sebagai penggunaan bahasa secara khusus terdiri atas interaksi atau dialog di antara penutur (Sinar, 2012:1).

$$
\text { Wacana tulis atau written }
$$
discourse adalah wacana yang disampaikan secara tertulis, melalui media tulis (Tarigan, 1987: 52). Wacana lisan atau spoken discourse adalah wacana yang disampaikan secara lisan, melalui media lisan (Tarigan 1987:55).

Pragmatik adalah salah satu
cabang linguistik yang menelaah
mengenai maksud ujaran yang
disesuaikan dengan konteksnya.
Pragmatik erat sekali hubungannya
dengan peristiwa tutur, aspek-aspek


situasi tutur, dan tindak tutur (Wijana, 1996:3).

Peristiwa tutur (speech event) adalah terjadinya atau berlangsungnya interaksi linguistik dalam satu bentuk ujaran atau lebih yang melibatkan dua pihak, yaitu penutur dan lawan tutur, dengan satu pokok tuturan, di dalam waktu, tempat, dan situasi tertentu (Chaer dan Agustina, 2010:47).

Leech (1993) mengemukakan sejumlah aspek yang senantiasa harus dipertimbangkan dalam studi pragmatik. Aspek-aspek tersebut adalah sebagai berikut: (1) Penutur dan lawan tutur, (2) Konteks tuturan, (3) Tujuan tuturan, (4) Tuturan sebagai bentuk tindakan atau aktivitas, (5) Tuturan sebagai produk tindak verbal

Searle dalam Nadar (2009:12) mengembangkan hipotesa bahwa pada hakikatnya semua tuturan mengandung arti tindakan, dan bukan hanya tuturan yang mempunyai kata kerja performatif. Unsur yang paling kecil dalam komunikasi adalah tindak tutur seperti menyatakan, membuat, pertanyaan, memberi perintah, menguraikan, menjelaskan, meminta maaf, berterima kasih, dan mengucapkan selamat. Tindak tutur menjadi dasar bagi analisis topik-topik pragmatik seperti praanggapan, implikatur percakapan, prinsip kerja sama, dan prinsip kesantunan.

Tindak lokusi adalah tindak tutur untuk menyatakan sesuatu. Tidak tutur ini disebut sebagai The Act of Saying Something. Fungsi tuturan llokusi untuk mengatakan atau menginformasikan sesuatu, dapat juga dipergunakan untuk melakukan sesuatu Tindak ilokusi disebut dengan The Act of Doing Something. (Wijana, 1996: 18). Tindak tutur yang pengutaraannya dimaksudkan untuk mempengaruhi lawan tutur disebut dengan tindak tutur perlokusi (Wijana, 1996:19).

\section{METODE}

Metode yang digunakan dalam penelitian ini ialah metode deskriptif kualitatif yaitu metode yang diarahkan untuk mendeskripsikan tindak tutur ilokusi yang digunakan guru bahasa Indonesia dalam proses pembelajaran di kelas XI IPA 1 SMA Negeri 9 Kota Bengkulu.

Sumber data dalam penelitian ini adalah interaksi berupa percakapan antara guru bahasa Indonesia dan siswa dalam proses pembelajaran di kelas XI IPA 1 SMA Negeri 9 Kota Bengkulu. Data dalam penelitian ini adalah tindak tutur ilokusi yang digunakan guru bahasa Indonesia dalam proses pembelajaran di kelas XI IPA 1 SMA Negeri 9 Kota Bengkulu.

Teknik pengumpulan data yang digunakan pada penelitian ini adalah: 1 . Observasi, 2. Teknik rekaman, 3. wawancara. Dalam penelitian ini penulis menggunakan teknik observasi nonpartisipan artinya penulis tidak ikut dalam kegiatan belajar mengajar, akan tetapi mengamati kegiatan belajar mengajar tersebut. Penulis menggunakan lembar observasi untuk mengetahui tindak tutur ilokusi guru bahasa Indonesia dalam proses pembelajaran. Observer dalam penelitian ini adalah peneliti itu sendiri.

Rekaman yang dimaksud dalam penelitian ini adalah merekam ujaran guru dan siswa dalam proses belajar mengajar menggunakan kamera digital yaitu "Fuji Kamera Finepix S4200" dengan tipe kamera DSLR Like. Data yang direkam adalah tuturan guru bahasa Indonesia dan siswa dalam interaksi belajar mengajar di SMA Negeri 9 Kota Bengkulu kelas XI IPA 1. Alat ini digunakan untuk merekam tindak tutur ilokusi guru bahasa Indonesia dan siswa dalam proses pembelajaran di 
kelas XI IPA 1 SMA Negeri 9 Kota Bengkulu.

Peneliti menggunakan teknik wawancara tidak terstruktur, untuk mengetahui tindak tutur yang digunakan guru dalam proses pembelajaran. Berdasarkan hasil wawancara diketahui bahwa dalam proses pembelajaran guru bahasa Indonesia menggunakan tindak tutur ilokusi asertif, direktif, komisif, dan ekspresif sehingga mempermudah penulis untuk memperoleh data berupa tindak tutur ilokusi guru bahasa Indonesia dalam proses pembelajaran di kelas XI IPA 1 SMA Negeri 9 Kota Bengkulu.

Penulis menggunakan teknik analisis data yang diperoleh dari hasil rekaman yang berisi interaksi guru bahasa Indonesia dan siswa dalam proses pembelajaran di kelas XI IPA 1 SMA Negeri 9 Kota Bengkulu. Langkah-langkah yang dilakukan dalam menganalisis data yaitu: 1. Pentranskripsian data, 2. Pengkodean data, 3. Pengklasifikasian data, 4. Penginterpretasian data, 5. Penyimpulan data, setelah dianalisis maka peneliti membuat kesimpulan dari hasil analisis data.

Untuk mendapatkan keabsahan data dalam penelitian diperlukan pemeriksaan. Pemeriksaan keabsahan data dilakukan dengan teknik triangulasi. teknik triangulasi adalah teknik yang dilakukan untuk menguji kredibilitas data kepada sumber yang sama dengan data yang berbeda (Sugiyono, 2014:6). Mensahihkan data dengan tiga teknik yakni teknik observasi, wawancara, dan teknik rekam untuk sumber data yang sama secara serentak. Ketiga teknik tersebut digunakan untuk mendeskripsikan tindak tutur ilokusi guru bahasa Indonesia dalam proses pembelajaran di kelas XI IPA 1 SMA Negeri 9 Kota Bengkulu.

\section{HASIL DAN PEMBAHASAN}

Berdasarkan analisis data diperoleh jenis tindak tutur ilokusi asertif, tindak tutur ilokusi direktif, tindak tutur ilokusi komisif dan tindak tutur ilokusi ekspresif. Tindak tutur ilokusi asertif terdiri dari tindak tindak tutur ilokusi asertif menyatakan informasi, tindak tutur ilokusi asertif mengemukakan pendapat, tindak tutur ilokusi asertif kesimpulan, dan tindak tutur ilokusi asertif menegaskan. Tindak tutur ilokusi direktif terdiri dari tindak tutur ilokusi direktif memerintah, dan tindak tutur ilokusi direktif meminta yang memiliki variasi di antaranya tindak tutur ilokusi direktif meminta respons, dan tindak tutur ilokusi direktif meminta menjawab. Tindak tutur ilokusi komisif terdiri dari tindak tutur ilokusi komisif berjanji dan tindak tutur ilokusi komisif menolak. Tindak tutur ilokusi ekspresif terdiri dari tindak tutur ilokusi ekspresif memuji, dan tindak tutur ilokusi ekspresif terima kasih.

\section{Tindak Tutur llokusi Asertif pada Proses Pembelajaran di Kelas XI IPA 1 SMA Negeri 9 Kota Bengkulu}

Asertif ialah jenis tindak tutur yang menyatakan apa yang akan diyakini penutur kasus atau bukan. Misalnya, pernyataan suatu fakta, menyatakan, melaporkan, mengemukakan pendapat, kesimpulan, menegaskan, dan mengusulkan (Yule, 1996:92).

Pada hasil penelitian ditemukan contoh tindak tutur ilokusi asertif yang terdiri atas: tindak tutur ilokusi asertif menyatakan informasi, tindak tutur ilokusi asertif mengemukakan pendapat, tindak tutur ilokusi asertif kesimpulan dan tindak tutur ilokusi asertif menegaskan.

Contoh tindak tutur ilokusi asertif menyatakan informasi di dalam proses pembelajaran yang terdapat data 11 lampiran 3 tabel klasifikasi data yaitu 
"Standar kompetensinya membaca. Contoh tuturan yang berbeda yang berisi tindak tutur ilokusi asertif menjelaskan ditemukan oleh Kolamiah (2011) dengan konteks yang berbeda (Analisis Tindak Tutur Ilokusi Guru Bahasa Indonesia dalam Interaksi Belajar Mengajar Kelas VII SMP Muhammadiyah 7 Banyudono Boyolali).

Contoh tindak tutur ilokusi asertif mengemukakan pendapat di dalam proses pembelajaran yang terdapat pada data 49 lampiran 3 tabel klasifikasi data yaitu "Belum, belum terpikirkan. Ya". Contoh tuturan yang berbeda yang berisi tindak tutur ilokusi asertif menyetujui ditemukan oleh Kolamiah (2011) dengan konteks yang berbeda (Analisis Tindak Tutur llokusi Guru Bahasa Indonesia dalam Interaksi Belajar Mengajar Kelas VII SMP Muhammadiyah 7 Banyudono Boyolali).

Contoh tindak tutur ilokusi asertif kesimpulan di dalam proses pembelajaran yang terdapat pada data 48 lampiran 3 tabel klasifikasi data yaitu "Jadi..... Contoh tuturan yang berbeda yang berisi tindak tutur ilokusi asertif menyebutkan ditemukan oleh Kolamiah (2011) dengan konteks yang berbeda (Analisis Tindak Tutur Ilokusi Guru Bahasa Indonesia dalam Interaksi Belajar Mengajar Kelas VII SMP Muhammadiyah 7 Banyudono Boyolali).

Contoh tindak tutur ilokusi asertif menegaskan di dalam proses pembelajaran yang terdapat pada data 85 lampiran 3 tabel klasifikasi data yaitu "Nah, ada sedikit tambahan ya....

Contoh tuturan yang berisi tindak tutur ilokusi asertif menegaskan ditemukan oleh Kolamiah (2011) dengan konteks yang berbeda (Analisis Tindak Tutur Ilokusi Guru Bahasa Indonesia dalam Interaksi Belajar Mengajar Kelas VII SMP Muhammadiyah 7 Banyudono Boyolali).

\section{Tindak Tutur Ilokusi Direktif pada Proses Pembelajaran di Kelas XI IPA 1 SMA Negeri 9 Kota Bengkulu}

Direktif ialah jenis tindak tutur yang dipakai oleh penutur untuk menyuruh orang lain melakukan sesuatu tuturan ini meliputi: perintah (menyuruh), meminta, menyarankan, mengajak, memohon, menganjurkan, menuntut, dan memberi nasihat (Yule, 1996:93).

Pada hasil penelitian ditemukan tindak tutur ilokusi direktif memerintah/menyuruh tindak tutur ilokusi direktif dan meminta. variasi tindak tutur ilokusi direktif di antaranya tindak tutur ilokusi direktif meminta menjawab dan tindak tutur ilokusi direktif meminta respons.

Contoh tindak tutur ilokusi direktif memerintah/menyuruh di dalam proses pembelajaran yang terdapat pada data 34 lampiran 3 tabel klasifikasi data yaitu "Jalan cerita. Tuliskan!..... Contoh tuturan yang berisi tindak tutur ilokusi direktif menyuruh ditemukan oleh Kolamiah (2011) dengan konteks yang berbeda (Analisis Tindak Tutur Ilokusi Guru Bahasa Indonesia dalam Interaksi Belajar Mengajar Kelas VII SMP Muhammadiyah 7 Banyudono Boyolali).

Contoh tindak tutur ilokusi direktif meminta jawaban di dalam proses pembelajaran yang terdapat pada data 93 lampiran 3 tabel klasifikasi data yaitu "....apakah itu ringkasan, ringkasan atau merangkum?....". Contoh tuturan yang berbeda yang berisi tindak tutur ilokusi direktif menuntut ditemukan oleh Kolamiah (2011) dengan konteks yang berbeda (Analisis Tindak Tutur Ilokusi Guru Bahasa Indonesia dalam Interaksi Belajar Mengajar Kelas VII SMP Muhammadiyah 7 Banyudono Boyolali). 
3. Tindak Tutur Ilokusi Komisif pada Proses Pembelajaran di Kelas XI IPA 1 SMA Negeri 9 Kota Bengkulu

Komisif ialah jenis tindak tutur yang dipahami oleh penutur untuk mengikatkan dirinya terhadap tindakantindakan di masa yang akan datang. Tindak tutur ini dapat berupa: janji, penolakan, ikrar, menjanjikan, menawarkan, menyatakan kesanggupan, dan berkaul (Yule, 1996:94).

Pada hasil penelitian ditemukan tindak tutur ilokusi komisif diantaranya tindak tutur ilokusi komisif berjanji dan tindak tutur ilokusi komisif menolak.

Contoh tindak tutur ilokusi komisif berjanji di dalam proses pembelajaran yang terdapat pada data 10 lampiran 3 tabel klasifikasi data yaitu "lya, berikutnya kita lanjut pada materi hikayat". Contoh tuturan yang berbeda yang berisi tindak tutur komisif bertanya ditemukan oleh Kolamiah (2011) dengan konteks yang berbeda (Analisis Tindak Tutur Ilokusi Guru Bahasa Indonesia dalam Interaksi Belajar Mengajar Kelas VII SMP Muhammadiyah 7 Banyudono Boyolali).

Contoh tindak tutur ilokusi komisif menolak di dalam proses pembelajaran yang terdapat pada data 81 lampiran 3 tabel klasifikasi data yaitu "Ceritakan sedikit saja. Ibu minta waktunya sedikit lagi". Contoh tuturan yang berbeda yang berisi tindak tutur komisif mengancam ditemukan oleh Kolamiah (2011) dengan konteks yang berbeda (Analisis Tindak Tutur Ilokusi Guru Bahasa Indonesia dalam Interaksi Belajar Mengajar Kelas VII SMP Muhammadiyah 7 Banyudono Boyolali).

\section{Tindak Tutur Ilokusi Ekspresif pada Proses Pembelajaran di Kelas XI IPA 1 SMA Negeri 9 Kota Bengkulu}

Ekspresif ialah jenis tindak tutur yang menyatakan sesuatu yang dirasakan oleh penutur. Tindak tutur itu mencerminkan pernyataan-pernyataan psikologis dan dapat berupa pernyataan kegembiraan, kritikan, kebencian, kesenangan, kesengsaraan, terima kasih, mengucapkan selamat, meminta maaf, mengeluh, mengecam, memuji, dan mengucapkan belasungkawa. Pada hasil penelitian ditemukan tindak tutur ilokusi ekspresif diantaranya tindak tutur ilokusi ekspresif terima kasih dan tindak tutur ilokusi ekspresif memuji (Yule, 1996:93).

Contoh tindak tutur ilokusi ekspresif terima kasih di dalam proses pembelajaran yang terdapat pada data 87 lampiran 3 tabel klasifikasi data yaitu "Ya terima kasih.".

Contoh tuturan yang berbeda yang berisi tindak tutur ekspresif mengkritik ditemukan oleh Kolamiah (2011) dengan konteks yang berbeda (Analisis Tindak Tutur Ilokusi Guru Bahasa Indonesia dalam Interaksi Belajar Mengajar Kelas VII SMP Muhammadiyah 7 Banyudono Boyolali).

Contoh tindak tutur ilokusi ekspresif memuji di dalam proses pembelajaran yang terdapat pada data 17 lampiran 3 tabel klasifikasi data yaitu "Membangkitkan semangat juang. Benar. Bagus.....". Contoh tuturan yang berbeda yang berisi tindak tutur ekspresif ditemukan oleh Kolamiah (2011) dengan konteks yang berbeda (Analisis Tindak Tutur Ilokusi Guru Bahasa Indonesia dalam Interaksi Belajar Mengajar Kelas VII SMP Muhammadiyah 7 Banyudono Boyolali).

\section{PENUTUP}

\section{Kesimpulan}

Berdasarkan hasil penelitian yang telah dilakukan mengenai tindak tutur ilokusi pada proses pembelajaran di kelas XI IPA 1 SMA N 9 Kota Bengkulu dapat 
disimpulkan bahwa tindak tutur yang ditemukan berupa tindak tutur ilokusi asertif, tindak tutur ilokusi direktif, tindak tutur ilokusi komisif, dan tindak tutur ilokusi ekspresif. Simpulan masing-masing tindak tutur itu sebagai berikut:

1. Tindak tutur ilokusi asertif yang ditemukan terdiri dari tindak tutur ilokusi asertif menyatakan informasi, tindak tutur ilokusi asertif mengemukakan pendapat, tindak tutur ilokusi asertif kesimpulan, dan tindak tutur ilokusi asertif menegaskan. Salah satu contoh tindak tutur ilokusi asertif adalah menyatakan informasi yang terdapat pada data 11 lampiran 3 tabel klasifikasi data, seperti contoh di bawah ini

"Standar kompetensinya membaca, kemudian kompetensi dasarnya menemukan unsur-unsur intrinsik.Ya, kita masuk pada kompetensi dasar menemukan unsur-unsur intrinsik dan ekstrinsik hikayat, novel Indonesia, dan novel terjemahan. Yang kita bahas sekarang terkhusus kepada hikayat."

Tuturan di atas termasuk salah satu contoh tindak tutur ilokusi asertif, intinya tindak tutur ilokusi asertif adalah tindak tutur yang berisi informasi yang terikat pada kebenaran proposisi yang diungkapkan.

2. Tindak tutur ilokusi direktif yang ditemukan terdiri dari tindak tutur ilokusi direktif memerintah/ menyuruh, dan tindak tutur ilokusi direktif meminta. Jenis tindak tutur ilokusi direktif meminta mempunyai variasi di antaranya tindak tutur ilokusi direktif meminta respons, dan tindak tutur ilokusi direktif meminta menjawab. Salah satu contoh tindak tutur ilokusi direktif adalah memerintah/menyuruh yang terdapat pada data 34 lampiran 3 tabel klasifikasi data, seperti contoh di bawah ini:

"Jalan cerita. Tuliskan!" (guru meminta salah satu siswa menuliskan di papan tulis)

Tuturan di atas termasuk salah satu contoh tindak tutur ilokusi direktif, intinya tindak tutur ilokusi direktif adalah tindak tutur yang bertujuan menghasilkan suatu efek berdasarkan tuturan yang ada.

3. Tindak tutur ilokusi komisif yang ditemukan terdiri atas tindak tutur ilokusi komisif berjanji dan tindak tutur ilokusi komisif menolak. Salah satu contoh tindak tutur ilokusi komisif adalah menolak yang terdapat pada data 81 lampiran 3 tabel klasifikasi data, seperti contoh di bawah ini:

"Ceritakan sedikit saja. Ibu minta waktunya sedikit lagi"

Tuturan di atas termasuk salah satu contoh tindak tutur ilokusi komisif, intinya tindak tutur ilokusi komisif adalah tindak tutur yang dipahami oleh penutur untuk mengikatkan dirinya terhadap tindakan-tindakan di masa yang akan datang.

4. Tindak tutur ilokusi ekspresif yang ditemukan yaitu tindak tutur ilokusi ekspresif memuji, dan tindak tutur ilokusi terima kasih. Salah satu contoh tindak tutur ilokusi ekspresif adalah memuji yang terdapat pada data 11 lampiran 3 tabel klasifikasi data, seperti contoh di bawah ini:

"Terima kasih untuk Erwinda dan Sari, ya, silahkan kembali ke tempatnya. Jadi, sudah jelas itu bagaimana cara meringkas, ya, merangkum isi buku, ya, pada hakikatnya pokok-pokok yang kita dapatkan, kita buat, rangkumannya kita kembangkan, dan ini tadi hasil diskusinya." 
Tuturan di atas termasuk salah satu contoh tindak tutur ilokusi ekspresif, intinya tindak tutur ilokusi ekspresif adalah tindak tutur yang mengungkapkan atau mengutarakan sikap psikologis penutur terhadap keadaan yang tersirat dalam ilokusi.

\section{Saran}

Penelitian ini membahas mengenai tindak tutur ilokusi pada proses pembelajaran di kelas XI IPA 1 SMA N 9 Kota Bengkulu. Diharapkan untuk penelitian selanjutnya mengenai tindak tutur ilokusi dalam proses pembelajaran di sekolah memperbanyak data (tindak tutur ilokusi guru dan siswa) sehingga semua jenis tindak tutur dapat ditemukan. Selain itu untuk penelitian selanjutnya disarankan dapat mengambil konteks di Pengadilan Agama, misalnya persidangan.

\section{DAFTAR PUSTAKA}

Chaer, A. 2010. Kesantunan Berbahasa. Jakarta: PT Rineka Cipta.
Kolamiah, S. 2011. Analisis Tindak Tutur Ilokusi Guru Bahasa Indonesia dalam Interaksi Belajar Mengajar Kelas VII SMP Muhammadiyah 7 Banyudono Boyolali. Skripsi diterbitkan Universitas Muhammadiyah Surakarta.

Leech, G. 1993. Prinsip-Prinsip Pragmatik (Diterjemahkan oleh M.D.D Oka). Jakarta: Universitas Pers Indonesia.

Sinar, T S. 2012. Teori \& Analisis. Medan: CV Mitra Medan.

Sugiyono. 2014. Metode Penelitian Kuantitatif, Kualitatif, dan $R \& D$. Bandung: Alfabeta.

Tarigan, H. G. 1987. Pengajaran Wacana . Bandung: Angkasa Bandung.

Wijana, I D. 1996. Dasar-dasar Pragmatik. Yogyakarta: Andi Offset.

Yule, G. 1996). Pragmatik (Diterjemahkan oleh Indah Fajar Wahyuni). Yogyakarta: Pustaka Belajar. 